Bolm. Zool., Univ. S. Paulo $4: 65-74,1979$

\title{
GENERAL BEHAVIORAL PATTERNS AND LIFE-CYCLE OF THE COLONIAL SPIDER, ERIOPHORA BISTRIATA (ARANEIDA: ARGIOPIDAE).
}

\author{
Nivar Gobbi, \\ Ronaldo Zucchi and Shôichi F. Sakagami \\ Departamento de Biologia (Setor de Ecologia), \\ Faculdade de Filosofia, Ciéncias e Letras de \\ Ribeirão Preto (USP) 14.100 Ribeirāo Preto (SP) \\ Brazil and Zoological Institute, Faculty of Sciences, \\ Hokkaido University, Sapporo (060), Japan.
}

\section{RESUMO}

Neste estudo, apresentamos observações preliminares do comportamento e biologia da aranha gregária Eriophora bistriata.

O trabalho inclui alguns aspectos da organização social, obtidos através de estudos de laboratório e campo. São inicialmente descritos, além do ciclo básico, algumas interaçōes como: construção de teia comum de caça, ausência de hostilidade inter-individual, alimentação comunal, comportamento reprodutor etc.

Os resultados obtidos permitiram comparar Eriophora bistriata, com outras espécies gregárias segundo o esquema evolutivo de Shear (1970: pag. 73).

\section{ABSTRACT}

This paper deals with observations on the gregarious spider Eriophora bistriata (Rengger 1836). This species lives in large colonies and spends most part of the day inside a silken nest which encloses twigs and leaves too.

Observations were conducted using colonies in the field but some aspects were developed in laboratory. Special emphasis is placed on life cycle and its components, communal hunting web, absence of inter-individual hostility, reproduction etc.

The results were compared with the ones obtained in species with similar (gregarious) type of life. 


\section{INTRODUCTION}

The majority of spiders are marked by solitarism and cannibalism. Such traits are sufficient to label the group as showing a generalized strong antagonistic behavior expressed as such even among individuals of the same species, batches or sexes.

Under this general aspect it is obvious that the members presenting social or gregarious tendencies attracted interest. Studies on colonial spiders were mentioned by Darwin (1845) and Wheeler (1928).

In his recent paper Shear (1970) records 8 spider families presenting colonial tendencies.

The majority is found among the cribellate families of araneomorph, or labidognath spiders, but Araneidae and Theridiidae, considered by the aracnologists among the specialized groups, share a small parcel of social groups too.

Among the colonial spiders the Agelenidae - Agelena consociata is the best studied species (Chauvin \& Denis 1965; Darchen 1965; Kraft 1970a, 1970b, 1971). The revisions made by Shear (1970) and Wilson (1971) are specially useful because from a comparative point of view they provided the basis for evolutionary studies concerning the aquisition of colonial behavior by spiders.

\section{MATERIAL AND METHODS}

The study was undertaken in colonies either under natural conditions or in laboratory. In our area Eriophora bistriata is a common inhabitant of the "cerrado" vegetation. Since the cerrado is becoming scanty due to intense man activity, the colonies were captured and transferred to the University Campus. The spiders were put in suitable places as similar as possible to the natural habitat. In all cases ( 3 transferences) the colonies established themselves very well in the new area.

To control specific conditions some colonies were transfered to $1 \mathrm{~m}^{3}$ woodenboxes.

In these at least one side was glass covered and another mesh provided, for ventilation purposes.

\section{RESULTS}

\section{i. General habits}

The behavior of this colonial spider alternates in a rhythmic way between daily quiescence inside the communal nest and nightly hunting activity. So, before going further, two important traits of its biology must be distinguished.

a. The communal nest a kind of ball shaped web where the spiders spend daytime. This is a permanent structure to which the colony members return daily.

b. The hunting communal web (fig. 1A), is a composed structure constructed every night, starting from the precedent structure to which it is tied by strong support threads. From there each individual spider constructs its hunting web and occupies 
its center. These individual webs are connected forming a large communal hunting web which is ingested (ref. Peakall, 1971) in the morning, leaving only the support threads attached to the communal nest.

The colonies were generally found in cerrado regions and mainly in the areas with a more scattered vegetation pattetn. This is probably related to the wide proportions (ca $-10 \mathrm{~m}$ ) of the communal hunting web that is normally spread through the clearings and fastened to the scattered shrubs or trees.

The communal nests are found either among the branches of trees or hidden entangled in shrubs. But this disposition is clearly age-related since the younger nests occupy lower positions while the mature ones prefer tree canopies.

The communal nest is made of strong whitish silken threads firmly attached to vegetation. The inclusion of leaves, twigs and branches gives it rigidity and turns it specially conspicuous.

Under daily normal condition the spiders occupy the inner parts of the nest and only a few can be seen outside. In the afternoon at twilight the spiders become gradually active and start the construction of the hunting web that remains extended overnight and is always constructed using the communal nesting spot as a basis to which the members return each morning through the support threads. Sometimes two sets of hunting webs are constructed parallely and in such cases the distance between them is $50 \mathrm{~cm}$ or more. Even the spiderlings can construct a web, just after leaving the cocoon or pouch that encloses the eggs. In this case the webs are just a miniature of the adult ones rarely being $1 \mathrm{~m}$ large.

Both sexes can construct a web and once the structure is finished each individual occupies the central position and never participates in the construction of its neighbours.

In the morning each individual web is ingested and generally by its owner. Only the support threads starting in the communal nest remain.

\section{Spider Activity}

As mentioned before the activity of the individuals is rhythmical. Activity starts in the late afternoon when spiders leave the communal nest gradually starting the construction of the individual webs which compose the large hunting web. In the morning of the next day, generally at $7 \mathrm{AM}$, all spiders enter the communal nest again. The communal hunting web mainly in adult aggregates, is not extended every night.

When a sudden rain surprises the spiders in the hunting web the way home is delayed. Aggregates composed of young individuals tend to start activity earlier, about $16,30 \mathrm{PM}$ and return earlier too at about $22 \mathrm{PM}$.

Jacson and Joseph (1973) observed that in Stegodyphus sarasinorum the females are more active than males. This is not the case in Eriophora bistriata.

Every individual web takes about 60 minutes to be constructed and after this the owner occupies the central position (fig. 1A).

Activity gradually diminishes in correlation to being well-fed and the return to the communal nest starts generally at $4 \mathrm{AM}$, despite sex or size. 


\section{Hunting activity}

This behavior is performed in groups or isolatedly and depends on the size of the prey. If the prey is small the spider in the center of the web attacks and eats it alone.

In the case of a larger prey the vibration it produces attracts neighbour spiders (fig. 1, B-C).

In this case the prey is enlaced by threads produced by the spinnerets and by threads from the web too. This causes constant damage to the web and no repair is provided.

No hostility exists among the individuals sharing the same prey and this prey sharing starts just after the spiderlings leave the protective case. When the reproductive period approaches the hunting behavior decreases. Under this situation a little number of active individuals remain in the communal nest.

\section{Reproductive period}

The reproductive phase starts after the sixth and seventh moults for males and females respectively and begins when some females do not return to the communal nest.

A dispersion phase follows, which may reach 100 meters, in some cases.

The young female has a dark and red spotted abdomen.

The spots become less and less evident as the moults proceed and at dispersion females are very conspicuous by their bright yellow coloration and abdominal enlargement.

It is interesting that at dispersion females show some solitary behavior. Even when dispersed every afternoon the web is constructed and hunting activity proceeds normaly.

When oviposition period approaches the spiders tend to quiescence, the web is no more constructed, the female staying under shrubs goes away or hides among branches of trees.

The gradative leaving of the female transforms the communal nest into a cluster of males. The only females present are the ones in which the last moulting is a little delayed but even these leave the aggregate at proper time.

The mating was not observed but it is possible that it takes place in the spot occupied by the solitary females since males were commonly found with them. alone.

The couple remains together for a few days and then the male leaves the female

If the evidences prove to be correct this would prevent inbreeding since the individuals of the same communal nest are the offspring of the same batch of eggs.

\section{Oviposition}

The oviposition is performed only by solitary females.

The abdomen just before egg delivery is so distended that the female is almost incapable of movements. The hunting web is no more distended and the female remains practically motionless.

The oviposition is generally performed in the vicinity of the communal nest and the egg case is attached to shrubs, tall grass and small trees (fig. 2-A). 


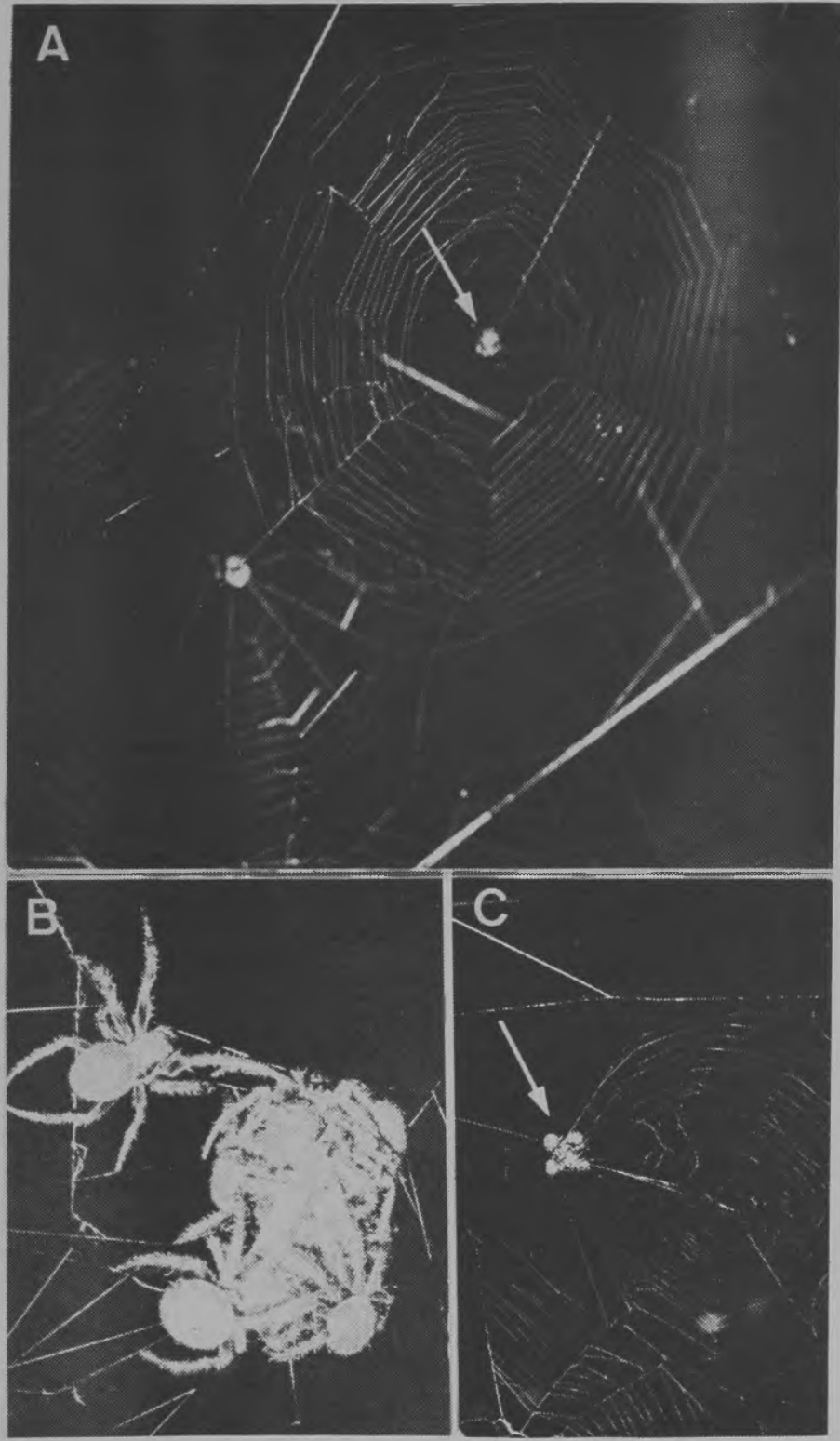

Fig. 1 Section of the hunting web and aspects of activity in the communal hunting. $\mathrm{A}, \mathrm{B}, \mathrm{C}$ - Explanation in the text. 


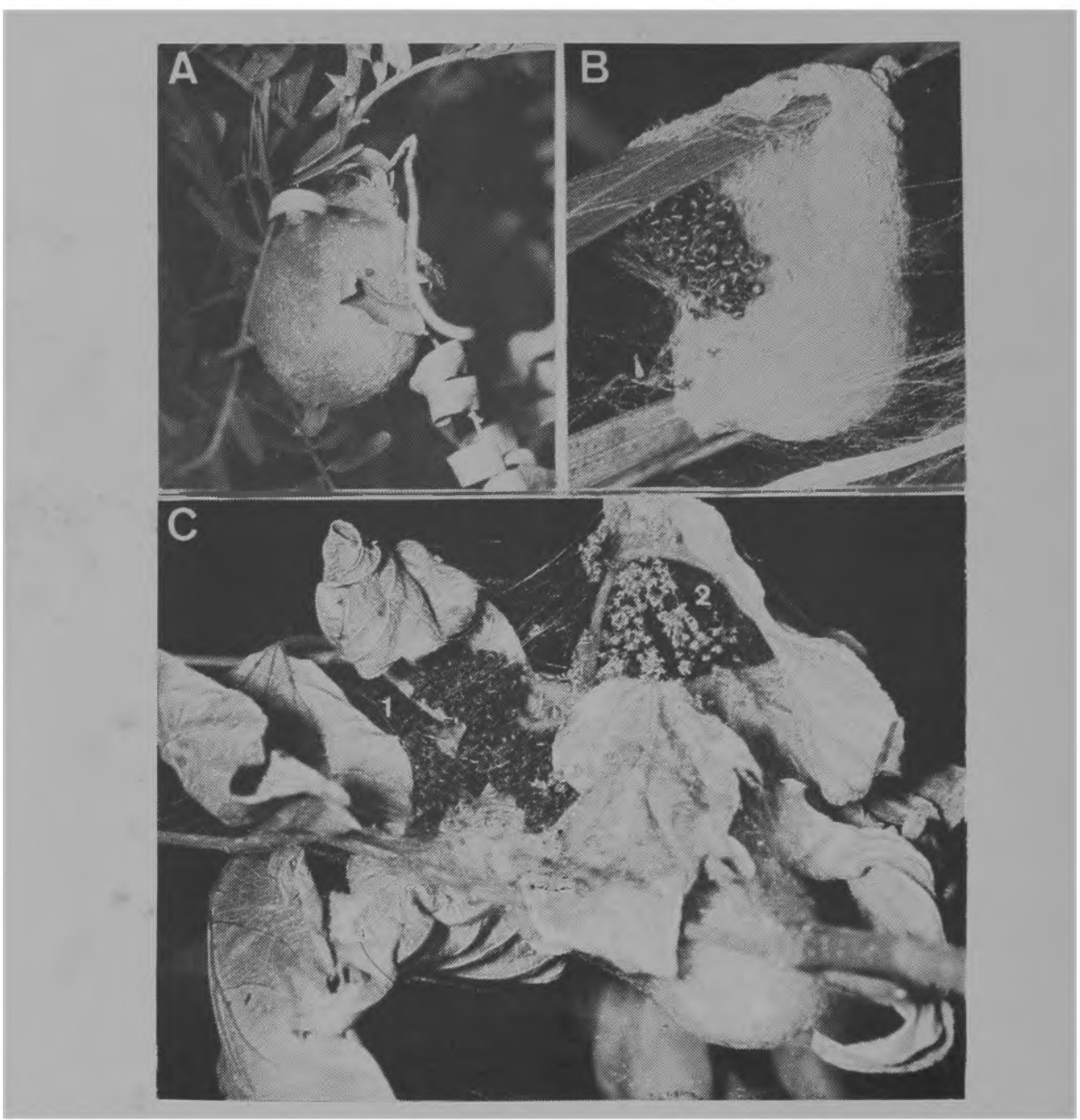

Fig. 2 Sequence of events related to oviposition, eclosion and moulting in Eriophora bistriata $A, B, C(1,2)$ - Explanation in the text.

In laboratory conditions the female constructs initially a kind of yellow bright silken support and oviposit over it. The egg when deposited shows a lenticular shape and over it the female spins the rest of the case.

The silken membrane is very resistent. Ants and other insects were seen trying, without success, to prey upon the eggs.

The mother spider dies a little after the oviposition. 


\section{The origin of the colony}

An aggregate is always the product of the oviposition of a single and solitary female. The main events involved are in table 1.

Table 1 - The main events in an aggregate from the oviposition period.

Oviposition

Emersion and first moulting

Leaving of the egg case or cocoon 2nd moulting

Making of the first hunting nest web

3rd moulting

$4^{\text {th }}$ moulting

5 th moulting

6th moulting

First external sexual evidences

7th moulting

Dispersion
$29 / 03 / 73$

$20 / 04 / 73$

$26 / 06 / 73$

$20 / 07 / 73$

$06 / 08 / 73$

$12 / 09 / 73$

$05 / 10 / 73$

$15 / 10 / 73$

$04 / 11 / 73$

$27 / 12 / 73$

$10 / 02 / 74$

$23 / 02 / 74$

The general sequence presented in table 1 happened also in the majority of other observed aggregates. The dispersion period occurred in late summer (under local climate), that is, at early March and April.

Only once an egg case was constructed in June (winter).

The spiderlings abandon the cocoon or egg case approximately three months after the oviposition and about two months after emersion (fig. 2-B).

The moultings occur at variable periods accompanying probably cycles of food availability. After each moulting (fig. 2-C-1) the colony leaves the spot and establishes itself in the surroundings (fig. 2-C-2).

The summation of all these events gives the biological cycle of the species a duration of 10-11 months.

\section{Population size}

The number of spiders in an aggregate depends upon the oviposition capacity of the mother female and also of the stage in the life cycle since each colony normally splits into several as the biological cycle progresses.

The oviposition rate of the females is also variable. In two instances from egg cases in the laboratory, we collected 13 and more than 500 emerging spiderlings.

In natural conditions aggregates were found in numbers which varied from 25 to more than 200 individuals. 


\section{Miscellaneous observations}

There is no detected hostility among the members of the aggregate.

When spinning the web the individual contacts are very peaceful. When they meet two of the same size one only deviates, that is one follows the normal route and the other rotates to the other side of the web so that they touch themselves by the external side of the body only. If the size of the individuals which meet is different the smaller one deviates and the bigger one remains in the same side of the web.

Hostility followed even by cannibalism was only once observed in a kit envolving caged individuals. Caged physogastric females were at two instances devoured by their partners (this may explain the sudden disappearing of one of the males in the dispersed couples, see item 3.4.).

Even in confined condition the basic rhythmic patterns of daily aggregation at night-hunting were observed.

\section{CONCLUSIONS}

The preliminary observations on the behaviour of Eriophora bistriata show some social or communal behavioral traits: colonial life, absence of hostility and cannibalism, construction of a communal hunting web, solitary or communal attacks onto the entangled preys etc.

The social traits allied to dispersion in the preoviposition period, probable after mating, after laying the individual egg sac etc. places Eriophora bistriata according to the evolutionary scheme by Shear (1970: pag. 73) in a level similar to Cyrtophora spp or Uloborus republicanus and in a step previous to Agelena consociata or Stegodyphus sarasinorum.

These last two groups present in addition to the common hunting web the contact between mother and sons.

\section{ACKNOWLEDGMENTS}

The paper received financial support from the Fundação de Amparo à Pesquisa do Estado de São Paulo (FAPESP) and Conselho Nacional de Desenvolvimento Científico e Tecnológico (CNPq). The species was identified by Dr. Persio de Biarsi (1972).

\section{LITERATURE CITED}

CHAUVIN, R. and J. DENIS 1965 Une araignée sociale au gabón. Biologia Gabonica, 1(2): 9399.

DARCHEN, R. 1965 Ethologie d'une araignée sociale Agelena consociata Denis. Biologia Gabonica, 1 (2): 117-146.

DARWIN, C. 1945 Voyage of the Beagle, annotated by Leonard Engel, 1962. Doubleday \& Company, Garden City, New York, 524 pp. 
JACSON, C.C. and K.J. JOSEPH 1973 Life history, bionomics and behaviour of the social spider Stegodyphus sarasinorum Karsch. Insectes Sociaux, 20 (2): 189-204.

KRAFFT, B. 1970a - Contribution à la biologie et à l'éthologie d'Agelena consociata Denis (Araignée sociale du Gabon). I. Biologia Gabonica, 3:197-301.

KRAFFT, B. 1970b - Contribution à la biologie et à l'éthologie d'Agelene consociata Denis (Araignée sociale du Gabon). II. Biologia Gabonica, 4:307-369.

PEAKALL, D.B. 1971 Conservation of web proteins in the spider Araneus diatematus. J. Exp. Zool:, 176 (3): 257-264.

SHEAR, W.A. 1970 - The evolution of social phenomena in spiders. Bulletin of the British Arachnological Society, 1 (5): 65-76.

WHEELER, W.M. 1928 - The Social Insects. Harcourt, Brance and Company. London, 378, pp.

WILSON, E.O. 1971 - The insect societies. Harvard University Press, Cambridge 548pp. 
